\title{
The promoter methylation of the Syk gene in nasopharyngeal carcinoma cell lines
}

\author{
CHONG YAN $^{1 *}$, CHIBO LIU ${ }^{2 *}$, QIAOZHI JIN ${ }^{1}$, ZHIHAI LI $^{1}$, BAOHONG TAO $^{1}$ and ZHIYI CAI ${ }^{1}$ \\ Departments of ${ }^{1}$ Otolaryngology - Head and Neck Surgery, and ${ }^{2}$ Clinical Laboratory, \\ Taizhou Municipal Hospital, Taizhou, Zhejiang 318000, P.R. China
}

Received March 9, 2012; Accepted June 14, 2012

DOI: $10.3892 / \mathrm{ol} .2012 .763$

\begin{abstract}
The aim of this study was to investigate the mRNA and protein expression levels of the Syk gene as well as its promoter methylation in nasopharyngeal carcinoma (NPC) cell lines. The CNE-1 (highly differentiated), CNE-2 (poorly differentiated) and NP69 (non-cancerous human immortalized nasopharyngeal epithelial cells) cell lines were used in the present study. The MS-PCR, Q-RT-PCR and western blotting methods were used to examine the Syk gene promoter methylation levels and mRNA and protein expression in the three cell lines. The promoter methylation levels in CNE-1, CNE-2 and NP69 cells were $36 \%, 62 \%$ and 0 , respectively. The mRNA levels in CNE-1 and CNE-2 cells were $42 \pm 3.5$ and $28 \pm 2 \%$ of that in NP69, respectively; the protein levels in CNE-1 and CNE-2 cells were $36 \pm 4.5$ and $16 \pm 2.5$ of that in NP69, respectively; the statistical differences between groups were significant. The lower differentiation levels of the NPC cell lines correlate with lower levels of mRNA and protein expression of the Syk gene, as well as higher promoter methylation levels.
\end{abstract}

\section{Introduction}

Nasopharyngeal carcinoma (NPC) is one of the most common types of malignant cancer, with a high occurrence rate in the Chinese population compared with the western population (1). The genetic mechanisms of oncogenesis include the inactivation of tumor suppression genes, such as p53, Rb and p16, as well as the overexpression of oncogenes, such as bcl-2, ras and Cyclin D1. However, the mutations of these genes are rare in NPC patients. One possibility is that the regulation of gene expression through promoter methylation is changed

Correspondence to: Dr Zhiyi Cai, Department of Otolaryngology Head and Neck Surgery, Taizhou Municipal Hospital, 381 Zhongshan Dong Road, Jiaojiang District, Taizhou, Zhejiang 318000, P.R. China E-mail: caizy008@tom.com

*Contributed equally

Key words: nasopharyngeal carcinoma, Syk gene, methylation, promoter in NPC cases $(2,3)$. The present study aimed to examine the differences in the mRNA and protein expression levels of the Syk gene as well as its promoter methylation in NPC cell lines with different differentiation levels, to understand the potential contribution of promoter methylation to NPC genesis.

\section{Materials and methods}

Materials. The NPC cell lines CNE-1, CNE-2 and NP69 were purchased from Yingrun Biotechnol Co. (Shanghai, China). The following reagents and instruments were used: Q-RT-PCR machine (ABI, Applied Biosystems, Carlsbad, CA, USA), Q-RT-PCR kit (Tiangen, Shanghai, China), keratinocyte-sfm culture medium (Invitrogen, Carlsbad, CA, USA), Genomic DNA extraction and purification kit, rabbit anti- $\beta$-actin, goat anti-rabbit secondary antibody, PVDF membrane, ECL kit (Kaiji Biotechnology, Shanghai, China).

Cell culture. The cell culture of the CNE-1, CNE-2 and NP69 cell lines was performed with complete RPMI-1640 medium at $37^{\circ} \mathrm{C}$ in a $5 \% \mathrm{CO}_{2}$ incubator. The cells were digested with $0.25 \%$ trypsin protease-EDTA.

$M S-P C R$. Following the DNA extraction, $8 \mu \mathrm{g}$ total DNA with $\mathrm{ddH}_{2} \mathrm{O}$ in a total volume of $18 \mu \mathrm{l}$ was heated at $95^{\circ} \mathrm{C}$ and then immediately placed into an ice water bath. $\mathrm{NaOH}(3 \mathrm{M})$ was added for denaturation at $42^{\circ} \mathrm{C}$ for $20 \mathrm{~min}$ and the solution was then mixed with freshly prepared hydroquinone and sodium bisulfite. Liquid paraffin $(200 \mu \mathrm{l})$ was added and incubated at $50^{\circ} \mathrm{C}$ for $16 \mathrm{~h}$. The liquid paraffin was then removed. The water phase was mixed with a purified solution of TBE buffer before de-salting with Wizard DNA purification system. An isopropanol wash was performed twice and DNA was eluted into $50 \mu \mathrm{ldd} \mathrm{d}_{2} \mathrm{O}$, then centrifuged before being incubated with $3 \mathrm{M} \mathrm{NaOH}$ at $37^{\circ} \mathrm{C}$ for $15 \mathrm{~min}$ for denaturation. Then $33 \mu \mathrm{l}$ of $10 \mathrm{M}$ ammonium acetate was added to buffer the $\mathrm{NaOH}$ before the ethanol was added to precipitate the DNA at $-70^{\circ} \mathrm{C}$ for $1 \mathrm{~h}$. Then the tube was centrifuged at $4^{\circ} \mathrm{C}$ at $10,000 \mathrm{x} \mathrm{g}$ for $20 \mathrm{~min}$. The DNA was washed with $70 \%$ ethanol after removing the supernatant. Finally the DNA was diluted in $50 \mu 1 \mathrm{TE}$ buffer and stored at $-20^{\circ} \mathrm{C}$. For the MS-PCR detection, methylation-specific primers contained $9 \mathrm{CpG}$ islands and non-methylation-specific primers contained $8 \mathrm{CpG}$ 
Table I. Sequences of methylation and non-methylation primers for the Syk gene promoter.

\begin{tabular}{ll}
\hline Primer & \multicolumn{1}{c}{ Sequences } \\
\hline Methylation & F: 5'-TTTCGGGTTTATGGGCGCGG-3' \\
& R: 5'-ACGAAAACGAACGCAACGCGAA-3' \\
Non-methylation & F: 5'GTTTTAGTTGATTTTTGTTTAGTTTTG-3' \\
& R: 5'-ACCACCCACTCCTCCTCACT-3'
\end{tabular}

F, upstream primer; R, downstream primer.

Table II. Sequences of Syk gene and GAPDH gene primers.

\begin{tabular}{ll}
\hline Gene & \multicolumn{1}{c}{ Sequences } \\
\hline Syk & F: 5'-CAT GTC AAG GAT AAG AAC ATC ATA GA-3' \\
& R: 5'-AGT TCA CCA CGT CAT AGT AGT AAT T-3' \\
GAPDH & F: 5'-ATG GCC TTC CGT GTC CCC ACT G-3' \\
& R: 5'-TGA GTG TGG CAG GGA CTC CCC A-3'
\end{tabular}

F, upstream primer; R, downstream primer.

islands. The reaction was performed as follows: methylation system: denaturation at $95^{\circ} \mathrm{C}$ for $5 \mathrm{~min}$, then 50 cycles of $95^{\circ} \mathrm{C}$ for $10 \mathrm{sec}$, annealing at $60^{\circ} \mathrm{C}$ for $15 \mathrm{sec}$ and extension at $72^{\circ} \mathrm{C}$ for $25 \mathrm{sec}$; non-methylation system: denaturation at $95^{\circ} \mathrm{C}$ for $5 \mathrm{~min}$, then 50 cycles of $95^{\circ} \mathrm{C}$ for $30 \mathrm{sec}$, annealing at $60^{\circ} \mathrm{C}$ for $15 \mathrm{sec}$ and extension at $72^{\circ} \mathrm{C}$ for $25 \mathrm{sec}$; with a final step at $72^{\circ} \mathrm{C}$ for $10 \mathrm{~min}$. PCR products $(5 \mu \mathrm{l})$ were used for $2 \%$ agarose gel electrophoresis and the image was analyzed for semi-quantitative absorbance values in order to calculate the methylation ratio [methylated primer band absorbance value/ (methylated primer extension increase in absorbance values + non-methylated primer band absorbance) $\mathrm{x}$ 100\%]. The sequences of the primers are listed in Table I.

$Q-R T-P C R$. RNA extraction was performed using the TRIzol approach with suspended cells and the purity was tested with the UV spectrophotometer A260/A280 ratio between 1.8 and 2.1. The $18 \mathrm{~S}$ and $28 \mathrm{~S}$ integrity were analyzed with agarose gel electrophoresis. For the cDNA synthesis reaction system, $2 \mu \mathrm{g}$ RNA was mixed with 10X RT mix, dNTP mix, $2 \mu \mathrm{l}$ Oligo-dT15, $1 \mu \mathrm{l}$ Quant Reverse Transcriptase and RNase Free $\mathrm{ddH}_{2} \mathrm{O}$ to a final volume of $20 \mu \mathrm{l}$. The mixture was incubated at $37^{\circ} \mathrm{C}$ for $60 \mathrm{~min}$. The SYBR-Green fluorescence dye was used during the real-time PCR. The $20-\mu 1$ reaction system included $9 \mu 1$ 2.5X Real Master mix/20X SYBR solution mixed reaction solution, $2 \mu \mathrm{l}$ cDNA solution, $2 \mu \mathrm{l}$ upstream and downstream primers $(100 \mathrm{nM})$ and $\mathrm{ddH}_{2} \mathrm{O}$ was added to make a final volume of $20 \mu \mathrm{l}$. Each sample was repeated 3 times. The reaction conditions were: pre-denaturation at $95^{\circ} \mathrm{C}$ for $2 \mathrm{~min}$, then 40 cycles of $95^{\circ} \mathrm{C}$ for $15 \mathrm{sec}, 62^{\circ} \mathrm{C}$ for $30 \mathrm{sec}$, $68^{\circ} \mathrm{C}$ for $60 \mathrm{sec}$; final reaction at $95^{\circ} \mathrm{C}$ for $15 \mathrm{sec}$ and $60^{\circ} \mathrm{C}$ for $1 \mathrm{~min}$, then $95^{\circ} \mathrm{C}$ for $15 \mathrm{sec}$. The fluorescence signals were collected for the melting curve analysis. The $\mathrm{Ct}$ value was recorded in the three repeated experiments and averaged, then calculated using the comparative $\Delta \Delta \mathrm{Ct}$ method. The sequences of primers are listed in Table II.

Western blot analysis. The total protein samples were transferred to PVDF membranes (positively charged Heni dragon film) following SDS-PAGE. The blocking was performed with $5 \%$ non-fat milk powder and the primary antibody was incubated at $4^{\circ} \mathrm{C}$ overnight. The incubation with the secondary antibody was performed at room temperature for $1 \mathrm{~h}$ prior to washing and ECL treatment and finally the X-ray film was developed. GADPH was used as an internal control. The image analysis system was used to find the absorbance value ratio between Syk and GADPH.

Statistical analysis. The SPSS 17.0 software was used for statistical analysis and the data are presented as mean \pm standard deviation. The single factor analysis of variance was used to compared the Syk promoter methylation rate and mRNA and protein expression differences among the cell lines. $\mathrm{P}<0.05$ was considered to indicate a statistically significant result.

\section{Results}

Promoter methylation in different cell lines. The electrophoresis results of the MS-PCR products suggest that CNE-1 and CNE-2 cells showed incomplete Syk promoter methylation (amplification with both groups of primers), while the NP69 cell line showed no promoter methylation (Fig. 1A). The methylation rates in CNE-1 and CNE-2 cells were statistically different at 36 and 62\%, respectively (Fig. 1B; $\mathrm{P}<0.01$ ).

Syk $m R N A$ expression in different cell lines. The melting curves of the Syk and GAPDH genes had single peaks at $80.57^{\circ} \mathrm{C}$ and $88.73^{\circ} \mathrm{C}$, respectively, suggesting high primer specificity. The 


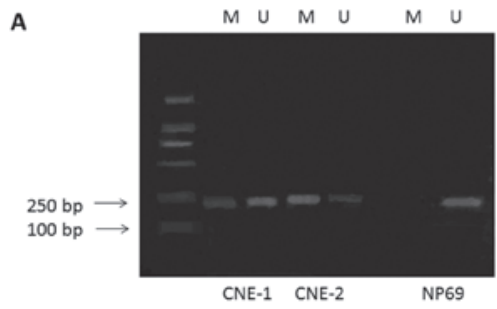

B

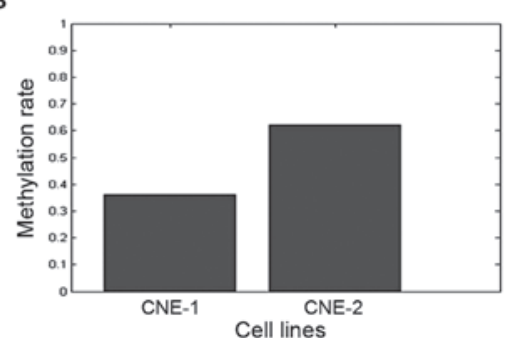

Figure 1. (A) MS-PCR electrophoresis image of the three cell lines. (B) Different methylation rate of the two NPC cell lines $[(\mathrm{M} / \mathrm{M}+\mathrm{U}) \times 100 \%)]$. $\mathrm{M}$, methylated primer band absorbance; $\mathrm{U}$, non-methylated primer band absorbance.

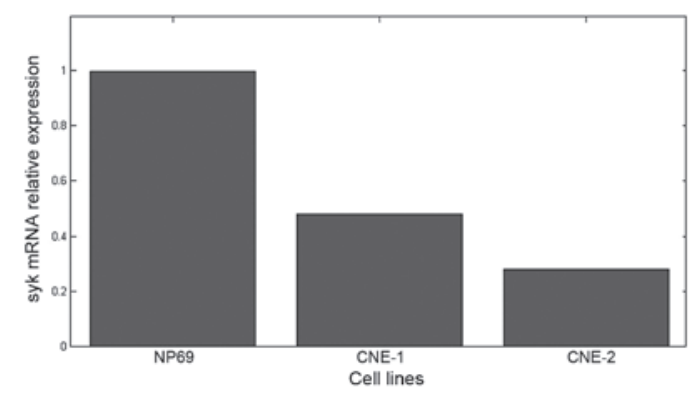

Figure 2. Syk mRNA expression levels in different cell lines (normalized to NP69).

A
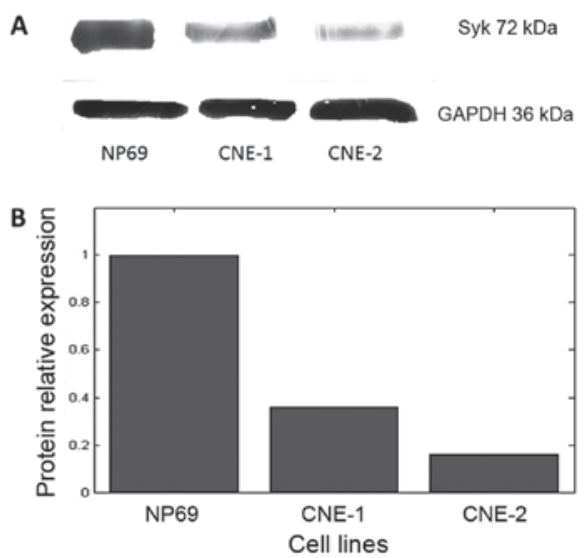

Figure 3. (A) Results of western blot analysis of the Syk protein. (B) Syk protein expression levels in different cell lines (normalized to NP69).

results of quantitative study of Syk gene expression are shown in Fig. 2. The mRNA was expressed in all three cell lines. The mRNA levels in CNE-1 and CNE-2 cells were lower, $42 \pm 3.5$ and $28 \pm 2 \%$ of that in NP69, respectively; the differences between the groups were statistically significant $(\mathrm{P}<0.01)$.
Syk protein expression in different cell lines. The results of the western blot analysis of Syk protein expression are shown in Fig. 3A. The protein was expressed in all three cell lines. The protein levels in CNE-1 and CNE-2 cells were lower, $36 \pm 4.5$ and $16 \pm 2.5 \%$ of that in NP69 (Fig. 3B), respectively; the differences between the groups were statistically significant $(\mathrm{P}<0.01)$.

\section{Discussion}

The epigenetic theory of cancer has emerged as a hot spot in recent years, especially for tumor suppressor genes $(4,5)$. The present study used NPC as the model to investigate the epigenetic changes of tumor suppressor genes. Syk is a non-receptor tyrosine kinase which was first identified in 1991 (6) and locates to the q22 region of human chromosome 9 . The protein contains 629 amino acids and has a molecular weight of $72 \mathrm{kDa}$. Syk is a significant molecule in the B cell antigenreceptor signaling pathway, and is considered to be a candidate tumor suppressor gene, the loss of which results in the retarded development and maturation of immune cells or even severe combined immunodeficiency (SCID) $(7,8)$. This may lead to the failure of monitoring cancer cell development and finally tumor growth.

The present study used NPC cells lines with varied levels of differentiation with NP69 as the control to examine the changes in the expression of the Syk gene and correlated changes in epigenetic control. The results revealed that the mRNA expression level in NP69 cells was higher than that in the NPC cell lines $(\mathrm{P}<0.01)$ and that in $\mathrm{CNE}-1$ cells the mRNA expression level was higher than that in $\mathrm{CNE}-2$ cells $(\mathrm{P}<0.01)$, suggesting a positive correlation between mRNA expression and the differentiation level; similar results were also observed for Syk protein expression. Finally, the methylation level of the Syk gene promoter was negatively correlated with the differentiation level.

Previous studies have suggested that the tumor suppression function of Syk is due to its inhibition of cell proliferation and migration, with the downregulation of its expression in breast, gastric, colorectal and liver cancer, among others (8-10). The detailed roles of Syk in NPC growth and metastasis are not clear. Recent studies have highlighted the roles of epigenetic changes of tumor suppressor genes in oncogenesis $(2,4,11,12)$. Our results are consistent with this theory, and the low differentiation level was associated with a low expression level of Syk and high methylation level of the promoter region. Further study is needed to elucidate the mechanism by which promoter methylation contributes to the altered expression of the Syk gene in NPC cell lines.

\section{References}

1. Tao Q and Chan AT: Nasopharyngeal carcinoma: molecular pathogenesis and therapeutic developments. Expert Rev Mol Med 9: 1-24, 2007.

2. Li LL, Shu XS, Wang ZH, Cao Y and Tao Q: Epigenetic disruption of cell signaling in nasopharyngeal carcinoma. Chin J Cancer 30: 231-239, 2011.

3. Lo KW and Huang DP: Genetic and epigenetic changes in nasopharyngeal carcinoma. Semin Cancer Biol 12: 451-462, 2002.

4. Niller $\mathrm{HH}$, Wolf $\mathrm{H}$ and Minarovits J: Epigenetic dysregulation of the host cell genome in Epstein-Barr virus-associated neoplasia. Semin Cancer Biol 19: 158-164, 2009. 
5. Buchholz TA and Wazer DE: Molecular biology and genetics of breast cancer development: a clinical perspective. Semin Radiat Oncol 12: 285-295, 2002

6. Taniguchi T, Kobayashi T, Kondo J, et al: Molecular cloning of a porcine gene syk that encodes a 72-kDa protein-tyrosine kinase showing high susceptibility to proteolysis. J Biol Chem 266: 15790-15796, 1991.

7. Medves S and Demoulin JB: Tyrosine kinase gene fusions in cancer: translating mechanisms into targeted therapies. J Cell Mol Med 16: 237-248, 2012.

8. Stewart ZA and Pietenpol JA: Syk: a new player in the field of breast cancer. Breast Cancer Res 3: 5-7, 2001.
9. Efremov DG and Laurenti L: The Syk kinase as a therapeutic target in leukemia and lymphoma. Expert Opin Investig Drugs 20: 623-636, 2011.

10. Page TH, Smolinska M, Gillespie J, Urbaniak AM and Foxwell BM: Tyrosine kinases and inflammatory signalling. Curr Mol Med 9: 69-85, 2009.

11. Simons MJ: Nasopharyngeal carcinoma as a paradigm of cancer genetics. Chin J Cancer 30: 79-84, 2011.

12. Hutajulu SH, Indrasari SR, Indrawati LP, et al: Epigenetic markers for early detection of nasopharyngeal carcinoma in a high risk population. Mol Cancer 10: 48, 2011. 